Santiagu John Mary ${ }^{1 *}$, Devadoss Delinta ${ }^{1}$, Asirvatham Ajila ${ }^{1}$, Annamalai Selvam ${ }^{1}$, Senthamarai Kannan Muthukumaran ${ }^{2}$, Susai Santhammal Rajendran ${ }^{3}$

${ }^{1} P G$ and Research Department of Chemistry, Loyola Institute of Frontier Energy, Loyola College, Tamil Nadu, India, ${ }^{2}$ Department of Chemistry, RKM Vivekananda College, Mylapore, Tamil Nadu, India, ${ }^{3} P G$ Department of Chemistry, Corrosion Research Centre St. Antony's College of Arts and Sciences for Women Thamaraipady, Tamil Nadu, India

Review paper

ISSN 0351-9465, E-ISSN 2466-2585

UDC: $669.018 .8: 544.6 .076 .2$

https://doi.org/10.5937/zasmat2103213M

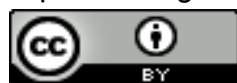

Zastita Materijala $62(3)$

$213-219(2021)$

\title{
Electrochemical behavior of various implantation biomaterials in the presence of various simulated body fluids-an overview
}

\begin{abstract}
In Modern medicine, metals and alloys are being used as implants. The Corrosion behaviour of various biomaterials under artificial body fluids are being studied. Artificial biomaterials are being implanted inside the human body to replace bone, teeth, etc. Even organs are being medically substituted with different types of metals such as mild steel, carbon steel, $\mathrm{Ni}-\mathrm{Cr}$ alloy, $\mathrm{Fe}-\mathrm{Cr}$ alloy, 22 carat Gold,24 carat Gold Tin, etc. due to their biocompatibility. This is achieved by connecting these metals directly with body tissues. The metals tend to corrode when it gets in contact with human body fluids. The body fluids thereby come in direct contact with tissues and the tissues are in contact with the metal thus causing the metal to corrode. And hence the corrosion resistance studies such as polarisation, AC impedance, cyclic voltammetric studies, etc, are being conducted in a medium like artificial blood plasma, artificial urine, artificial salvia, artificial sweat, Hank solution, Ringer solution, etc. The different body fluids are examined in the presence of different implantation metals by electrochemical methods and protective films are formed which are analyzed by various surface analysis techniques such as AFM, FTIR-UV, SEM, etc. The research findings will thereby be very helpful to the medical field.
\end{abstract}

Keywords: Corrosion, Hank solution, Alloy, Artificial body fluids.

\section{INTRODUCTION}

Metallic biomaterials are often employed in orthopedic and dental surgery, operative cardiology, and urological repair. Mechanical strength and biocompatibility, corrosion resistance, safety, ductility, and wear resistance are all desirable qualities in implant alloys[1-39]. Biomaterials such as mild steel, carbon steel, $\mathrm{Ni}-\mathrm{Cr}$ alloys, 22 carat Gold, 24 carat Gold, tin, etc, are being used in the human body for various medical purposes. These metals when comes in contact with the body fluids such as blood plasma, sweat,

\footnotetext{
${ }^{*}$ Corresponding author: Santiagu John Mary

E-mail: johnmarysj@gmail.com

Paper received: 1.07.2021.

Paper corrected: 20.07.2021.

Paper accepted: 27.07.2021.
}

Paper is available on the website: www.idk.org.rs/journal
Hank solution, etc, may tend to corrode. So the corrosion resistance of these metals in artificial body fluids is being studied in the presence and absence of inhibitors (additives) and results are being concluded with the Corrosion Resistance factors. Methods like SEM, TEM, AFM are commonly used to examine metals after their corrosion process. The detailed overview of various biomaterials and their recorded results are being summarised below [1-39].

Advance medical science uses metals and alloys as implants in human body. These metals may tend to corrode with time when they interact with body fluids. Thus the corrosion resistance of these metals are being studied in artificial body medium using various inhibitors (additives) and the corrosion resistance of these metals and alloys with suitable inhibitor is concluded. 
Table 1. The corrosion behavior of various metal and its alloys

Tabela 1. Korozijsko ponašanje različitih metala i njegovih legura

\begin{tabular}{|c|c|c|c|c|c|}
\hline $\begin{array}{l}\text { S. } \\
\text { No }\end{array}$ & METAL & MEDIUM & Additive & METHOD & FINDINGS ${ }^{(\text {Reference) }}$ \\
\hline 1. & $\begin{array}{l}\text { Mild Steel } \\
\text { Galvanised Steel } \\
\text { SS 316L }\end{array}$ & $\begin{array}{l}\text { Artificial } \\
\text { Sweat }\end{array}$ & - & $\begin{array}{l}\text { Potentiodynamic } \\
\text { Polarization }\end{array}$ & $\begin{array}{l}\text { Corrosion Resistance : } \\
\text { GS }>\text { SS } 316>\text { MS } \\
\text { Material Resistance : } \\
\text { SS } 316>\text { MS > GS } \\
\text { Compactness of the film: } \\
\text { SS316 > MS > GS }\end{array}$ \\
\hline 2 & $\begin{array}{l}\text { Mild steel } \\
\text { Ni-Ti super elastic } \\
\text { alloy }\end{array}$ & Artificial Urine & Urea & $\begin{array}{l}\text { Potentiondynamic } \\
\text { polarisation } \\
\text { Surface examination } \\
\text { Study } \\
\text { Scanning Electron } \\
\text { Microscopic Studies }\end{array}$ & $\begin{array}{l}\text { Ni-Ti has more Corrosion } \\
\text { resistance in absence of urea } \\
\text { than in presence } \\
\text { Mild steel has less corrosion } \\
\text { resistance in presence of urea } \\
\text { than in absence }\end{array}$ \\
\hline 3 & $\begin{array}{l}\text { Ni-Ti alloy } \\
\text { Thermoactive } \\
\text { alloy } \\
\text { SS 316L }\end{array}$ & Artificial saliva & Coffee & $\begin{array}{l}\text { Potentiodynamic } \\
\text { Polarisation study } \\
\text { AC Impedance } \\
\text { spectra }\end{array}$ & $\begin{array}{l}\text { Corrosion Resistance of alloys: } \\
\text { SS } 316 \mathrm{~L}>\text { Thermoactive alloy }> \\
\text { Ni-Ti alloy }{ }^{3}\end{array}$ \\
\hline 4 & $\begin{array}{l}\text { Mild steel } \\
\text { Mild steel coated } \\
\text { with Zn } \\
\text { SS } 316 \mathrm{~L}\end{array}$ & Artificial saliva & D-Glucose & $\begin{array}{l}\text { Potentiodynamic } \\
\text { Polarisation } \\
\text { AC } \\
\text { impendancespectra }\end{array}$ & $\begin{array}{l}\text { Corrosion Resistance the } \\
\text { absence and presence of D- } \\
\text { Glucose } \\
\text { SS } 316 \mathrm{~L}>\mathrm{MS}-\mathrm{Zn}>\mathrm{MS}^{4}\end{array}$ \\
\hline 5 & $\begin{array}{l}\mathrm{Zr}_{65} \mathrm{Cu}_{17.5} \mathrm{Ni}_{10} \mathrm{Al}_{7.5} \\
\left(\mathrm{Zr}_{60} \mathrm{Nb}_{5}\right) \mathrm{Cu}_{17.5} \mathrm{Ni}_{10} \\
\mathrm{Al}_{7.5} \\
\left(\mathrm{Zr}_{60} \mathrm{Nb}_{5}\right) \mathrm{Cu}_{17.5}\left(\mathrm{Ni}_{5}\right. \\
\mathrm{Pd}_{5} \mathrm{Al}_{7.5}\end{array}$ & $\begin{array}{l}\text { Artificial } \\
\text { Saliva } \\
\text { Phosphate } \\
\text { buffered } \\
\text { solution } \\
\text { Artificial Blood } \\
\text { plasma }\end{array}$ & - & $\begin{array}{l}\text { Electrochemical } \\
\text { polarisation } \\
\text { Galvanostatic-step } \\
\text { measurement }\end{array}$ & $\begin{array}{l}\text { Addition of } \mathrm{Nb} \text { enhanced the } \\
\text { corrosion resistance among the } \\
\mathrm{Zr} \text { - based Bulk Metallic Glasses } \\
(\mathrm{BGM})^{5}\end{array}$ \\
\hline 6 & Copper & $\begin{array}{l}\text { Artificial Blood } \\
\text { Plasma }\end{array}$ & $\begin{array}{l}\text { Adenine and } \\
2,6- \\
\text { diaminopurin } \\
\text { e potassium } \\
\text { sorbate }\end{array}$ & $\begin{array}{l}\text { Potentiodynamic } \\
\text { polarisation } \\
\text { Electrochemical } \\
\text { Impedance } \\
\text { spectroscopy } \\
\text { Cyclic voltammetry } \\
\text { measurements } \\
\end{array}$ & $\begin{array}{l}\text { Efficiency up till } 90 \% \text { was } \\
\text { provided with both compounds }\end{array}$ \\
\hline 7 & $\begin{array}{l}\text { AISI } 420 \\
\text { Custom } 630 \\
\text { Custom } 455\end{array}$ & $\begin{array}{l}\text { Artificial Blood } \\
\text { Plasma }\end{array}$ & - & $\begin{array}{l}\text { Potentiodynamic } \\
\text { polarisation } \\
\text { Electrochemical } \\
\text { Impedance analysis } \\
\text { Magnetic behaviour }\end{array}$ & $\begin{array}{l}\text { Custom } 630 \text { was the better } \\
\text { corrosion resistive material }{ }^{7}\end{array}$ \\
\hline 8 & $\begin{array}{l}\text { La added } 316 \mathrm{~L} \\
\text { stainless steel }\end{array}$ & $\begin{array}{l}\text { Simulated } \\
\text { Blood plasma } \\
\text { Hank's } \\
\text { solution }\end{array}$ & - & $\begin{array}{l}\text { Potentiodynamic } \\
\text { polarisation }\end{array}$ & $\begin{array}{l}\text { Corrosion Resistance of La } \\
\text { added } 316 \mathrm{~L} \text { stainless steel in } \\
\text { both solution is improved due } \\
\text { to the effect of La in the } \\
\text { purification of steel }^{8}\end{array}$ \\
\hline 9 & $\begin{array}{l}\mathrm{Zr}-\mathrm{Ti} \\
\mathrm{Zr}-\mathrm{Hf}\end{array}$ & $\begin{array}{l}\text { Hank's } \\
\text { Solution }\end{array}$ & - & $\begin{array}{l}\text { Potentiodynamic } \\
\text { polarisation } \\
\text { Homogenization } \\
\text { Heattreatment }\end{array}$ & $\begin{array}{l}\text { Addition of } \mathrm{Ti} \text { to } \mathrm{Zr} \text { over } 5 \% \\
\text { increases pitting corrosion } \\
\text { resistance. } \\
\text { Addition of Hf to Zrdecreased } \\
\text { the corrosion resistance }\end{array}$ \\
\hline
\end{tabular}




\begin{tabular}{|c|c|c|c|c|c|}
\hline 10 & $\begin{array}{l}\text { Ti5Al4V } \\
\text { Ti6al4V }\end{array}$ & $\begin{array}{l}\text { Ringer } \\
\text { solution } \\
\text { Phosphate } \\
\text { Buffer } \\
\text { solution }\end{array}$ & $\mathrm{H}_{2} \mathrm{O}_{2}$ & $\begin{array}{l}\text { Potentiodynamic } \\
\text { polarisation } \\
\text { Heat treatment } \\
\text { fabrication method }\end{array}$ & $\begin{array}{l}\text { The alloy was found to have } \\
\text { better corrosion resistance in } \\
\text { test solutions }{ }^{10}\end{array}$ \\
\hline 11 & $\begin{array}{l}\mathrm{Co}-\mathrm{Cr} \\
\mathrm{Ni}-\mathrm{Cr} \\
\mathrm{Cu}-\mathrm{Ni}-\mathrm{Al} \\
\text { Commercially pure } \\
\mathrm{Ti}(\mathrm{cpTi})\end{array}$ & $\begin{array}{l}\text { Artificial } \\
\text { Saliva }\end{array}$ & - & $\begin{array}{l}\text { Electrochemical } \\
\text { impedance } \\
\text { spectroscopy } \\
\text { Tafel\& cyclic } \\
\text { polarisation. }\end{array}$ & $\begin{array}{l}\text { Corrosion Rates } \\
\mathrm{Cu}-\mathrm{Ni}-\mathrm{Al}>\mathrm{cpTi}>\mathrm{Co}-\mathrm{Cr}>\mathrm{Ni}-\mathrm{Cr}> \\
\mathrm{Co}-\mathrm{Cr}^{11}\end{array}$ \\
\hline 12 & SS 316L & $\begin{array}{l}\text { Artificial Blood } \\
\text { Plasma }\end{array}$ & Amoxicillin & $\begin{array}{l}\text { Potentiodynamic } \\
\text { Polarization } \\
\text { Electrochemical } \\
\text { impedance Method }\end{array}$ & $\begin{array}{l}\text { Corrosion Resistance of SS } \\
316 L \text { in } A B p \text { is of the order: } \\
\text { SS316 + ABp }+10 p p m \\
\text { Amoxicillin }>S S 316+50 p p m+ \\
A B p>S S 316 L+A B p^{12}\end{array}$ \\
\hline 13 & $\begin{array}{l}\text { Mild Steel } \\
\text { Mild Steel coated } \\
\text { with Zinc } \\
\text { SS 316L }\end{array}$ & Artificial saliva & Spirulina & $\begin{array}{l}\text { Potentiodynamic } \\
\text { Polarization } \\
\text { Electrochemical } \\
\text { impedance Method }\end{array}$ & $\begin{array}{l}\text { SS } 316 \mathrm{~L} \text { and MS-Zn has more } \\
\text { Corrosion resistance in the } \\
\text { absence of Spirulina than in } \\
\text { their presence } \\
\text { MS has more Corrosion } \\
\text { Resistance in the presence of } \\
\text { spirulina than in their absence }\end{array}$ \\
\hline 14 & Ni-Cr Alloy & $\begin{array}{l}\text { Artificial } \\
\text { Saliva }\end{array}$ & $\begin{array}{l}\text { Metformin } \\
\text { Hydrochlorid } \\
\text { e (250 mg) }\end{array}$ & $\begin{array}{l}\text { Potentiodynamic } \\
\text { Polarization } \\
\text { AC Impedance } \\
\text { Method }\end{array}$ & $\begin{array}{l}\text { In the presence of Metformin } \\
\text { Hydrochloride the corrosion } \\
\text { resistance of } \mathrm{NiCr} \text { alloy } \\
\text { increases. }\end{array}$ \\
\hline 15 & $\begin{array}{l}\text { Fe-17Cr-8Ni alloy } \\
\text { Fe-7Cr-10Ni alloy } \\
\text { Fe-17 Cr-14Ni } \\
\text { alloy }\end{array}$ & $\begin{array}{l}\text { Stimulated } \\
\text { body fluid }\end{array}$ & $\begin{array}{l}\mathrm{H}_{2} \mathrm{O}_{2} \text { and } \\
\text { albumin }\end{array}$ & $\begin{array}{l}\text { Potentiodynamic } \\
\text { Polarization } \\
\text { Electrochemical } \\
\text { impedance Method }\end{array}$ & $\begin{array}{l}\text { Fe-Cr-14Ni alloy contains } \\
\text { smallest rate of corrosion than } \\
\text { Fe-17Cr-8Ni and Fe-17Cr-10Ni } \\
\text { alloys. } \\
\text { Fe-17Cr-14Ni obtained the } \\
\text { smallest corrosion rate due to } \\
\text { the protective oxide film } \\
\text { Fe-17Cr-8 } \mathrm{Ni}<\mathrm{Fe}-7 \mathrm{Cr}-10 \mathrm{Ni}< \\
\mathrm{Fe}-17 \mathrm{Cr}-14 \mathrm{Ni}{ }^{15}\end{array}$ \\
\hline 16 & $\begin{array}{l}\text { Mild steel } \\
\mathrm{Ni}-\mathrm{Ti} \text { super elastic } \\
\text { alloy }\end{array}$ & Artificial Urine & $\mathrm{NaCl}$ & $\begin{array}{l}\text { Potentiodynamic } \\
\text { Polarisation study }\end{array}$ & $\begin{array}{l}\mathrm{Ni}-\mathrm{Ti} \text { has more Corrosion } \\
\text { resistance in presence of } \mathrm{NaCl} \\
\text { than in absence } \\
\text { Mild steel has less corrosion } \\
\text { resistance in presence of } \mathrm{NaCl} \\
\text { than in absence. }^{16}\end{array}$ \\
\hline 17 & $\begin{array}{l}\text { Mild steel } \\
\text { 22-carat gold } \\
\text { 18-carat gold } \\
\text { Ni-Cr alloy } \\
\text { SS316L }\end{array}$ & $\begin{array}{l}\text { Ringer's } \\
\text { solution }\end{array}$ & - & $\begin{array}{l}\text { Electrochemical } \\
\text { impedance Method }\end{array}$ & $\begin{array}{l}\text { Corrosion Resistance : } \\
\text { Ni-Cr> Gold } 22>\text { SS } 316 \mathrm{~L}> \\
\text { Gold } 18>\text { mild steel }^{17}\end{array}$ \\
\hline 18 & $\begin{array}{l}\text { Austenitic } \\
\text { stainless steel Cr- } \\
\text { Ni-Mo }\end{array}$ & $\begin{array}{l}\text { Artificial Urine } \\
\text { Tyrode's } \\
\text { physiological } \\
\text { solution } \\
\text { Artificial } \\
\text { plasma }\end{array}$ & - & $\begin{array}{l}\text { Potentiodynamic } \\
\text { Polarization }\end{array}$ & $\begin{array}{l}\text { Cr-Ni-Mo steel shows better } \\
\text { corrosion resistance in } \\
\text { Tyrode's physiological } \\
\text { solution }{ }^{18}\end{array}$ \\
\hline
\end{tabular}




\begin{tabular}{|c|c|c|c|c|c|}
\hline 19 & $\begin{array}{l}\text { Ti-6Al-4V Alloy } \\
\text { with Nitride } \\
\text { coating }\end{array}$ & $\begin{array}{l}\text { Tyrode's } \\
\text { solution } \\
0.9 \% \mathrm{NaCl}\end{array}$ & - & $\begin{array}{l}\text { Chemical - Thermal } \\
\text { Treatment } \\
\text { X-ray phase } \\
\text { analysis } \\
\text { SEM } \\
\text { Electro Chemical } \\
\text { Test }\end{array}$ & $\begin{array}{l}\text { Ti-6Al-4V alloy has higher } \\
\text { corrosion resistance in } \\
\text { Tyrode's solution }{ }^{19}\end{array}$ \\
\hline 20 & $\begin{array}{l}\text { Austanitic } 304 \\
\text { Stainless Steel }\end{array}$ & $\begin{array}{l}\text { Tyrode's } \\
\text { physiological } \\
\text { solution }\end{array}$ & - & $\begin{array}{l}\text { Potentiodynamic } \\
\text { Polarization } \\
\text { AC Impedance } \\
\text { Method } \\
\text { SEM }\end{array}$ & $\begin{array}{l}\text { It was seen that electro } \\
\text { polishing increases the uniform } \\
\text { pitting corrosion in The } \\
\text { Austanitic } 304 \text { Stainless Steel }\end{array}$ \\
\hline 21 & $\begin{array}{l}\mathrm{Ni}-\mathrm{Ti} \\
\mathrm{Ni}-\mathrm{Tl}-\mathrm{Cu} \\
\text { Pure Ti } \\
\text { Ti-6-Al-4V } \\
316 \mathrm{~L}\end{array}$ & $\begin{array}{l}\text { Hank's } \\
\text { solution }\end{array}$ & - & $\begin{array}{l}\text { Potentiometric } \\
\text { polarization Method } \\
\text { Re Passivation Test }\end{array}$ & $\begin{array}{l}\text { The susceptibility to corrosion } \\
\text { of the order: } \\
\text { cpTi } \approx \mathrm{Ti} 6 \mathrm{Al} 4 \mathrm{~V}<<316 \mathrm{~L} \\
<\mathrm{NiTiCu}<\mathrm{NiTi} \\
\mathrm{Cp} \mathrm{Ti} \text { and Ti6Al4V are resistant } \\
\text { to the initiation of crevice } \\
\text { corrosion in Hank'ssolution } \\
\mathrm{Cu} \text { addition to NiTi improves } \\
\text { the repassivation capability by } \\
\text { EDS analysis }\end{array}$ \\
\hline 22 & Co-Cr-W-Ni alloy & $\begin{array}{l}\text { Artificial blood } \\
\text { plasma } \\
\text { Artificial urine } \\
\text { Tyrode } \\
\text { solution }\end{array}$ & - & $\begin{array}{l}\text { Electrochemical } \\
\text { impedance Method }\end{array}$ & $\begin{array}{l}\text { Co-Cr-W-Ni showed good } \\
\text { corrosion resistance }\end{array}$ \\
\hline 23 & $\begin{array}{l}\mathrm{Ti} \\
\text { Co-Cr Alloy }\end{array}$ & Artificial saliva & - & $\begin{array}{l}\text { Electrochemical } \\
\text { impedance Method }\end{array}$ & $\begin{array}{l}\text { Titanium was found to have } \\
\text { high Corrosion Resistance }\end{array}$ \\
\hline 24 & $\begin{array}{l}\text { AZ91D } \\
\text { Ti-6Al-4V }\end{array}$ & $\begin{array}{l}\text { Stimulated } \\
\text { blood fluids at } \\
37^{\circ} \mathrm{C}\end{array}$ & - & $\begin{array}{l}\text { Potentiometric } \\
\text { polarization Method } \\
\text { Electrochemical } \\
\text { impedance Method }\end{array}$ & $\begin{array}{l}\text { The corrosion resistance of } \\
\text { Titanium alloy was high } \\
\text { compared to Magnesium } \\
\text { alloy }^{24}\end{array}$ \\
\hline 25 & $\begin{array}{l}\mathrm{Co}-\mathrm{Cr} \\
\mathrm{Ni}-\mathrm{Cr} \text { alloy }\end{array}$ & Artificial saliva & $\begin{array}{l}\text { Streptococc } \\
\text { us mutans }\end{array}$ & $\begin{array}{l}\text { Potentiondynamic } \\
\text { Polarisation } \\
\text { Impedance } \\
\text { spectroscopy } \\
\text { Open circuit } \\
\text { potential } \\
\text { measurement }\end{array}$ & $\begin{array}{l}\text { The presence of Streptococcus } \\
\text { mutans reduced corrosion rate } \\
\text { of both alloys. }\end{array}$ \\
\hline 26 & $\begin{array}{l}\text { Mild steel } \\
\mathrm{Ni}-\mathrm{Cr} \\
\mathrm{SS}-316 \\
\mathrm{Cu}-\mathrm{Ni}-\mathrm{Ti} \\
\text { 22-carat gold } \\
\text { 24-carat gold } \\
\text { Super elastic } \mathrm{Ni}-\mathrm{Ti}\end{array}$ & $\begin{array}{l}\text { Artificial } \\
\text { Plasma }\end{array}$ & Glucose & $\begin{array}{l}\text { Tafel } \\
\text { electrochemical } \\
\text { impedance } \\
\text { spectroscopic } \\
\text { experiments }\end{array}$ & $\begin{array}{l}\mathrm{Ni}-\mathrm{Cr} \text { and SS_316 showed } \\
\text { good corrosion resistance both } \\
\text { in the absence and in the } \\
\text { presence of } 0.05 \mathrm{~g} \text { of glucose } \\
\text { The rest } 5 \text { metals showed good } \\
\text { corrosion resistance in small } \\
\text { amounts of glucose. }\end{array}$ \\
\hline 27 & $\begin{array}{l}\mathrm{Ni} \text {-Ti based alloys } \\
\text { (Super Elastics) }\end{array}$ & $\begin{array}{l}\text { Artificial } \\
\text { Saliva }\end{array}$ & $\begin{array}{l}\text { Sulfa drugs } \\
\text { like Phexin }\end{array}$ & Polarisation study & $\begin{array}{l}0.1 \mathrm{~g} \text { of phexin has more } \\
\text { corrosion resistance than } 0.05 \mathrm{~g} \\
\text { of phexin when added. }{ }^{27}\end{array}$ \\
\hline
\end{tabular}




\begin{tabular}{|l|l|l|l|l|l|}
\hline 28 & $\begin{array}{l}\text { Ni-Ti based alloys } \\
\text { (Super Elastics) }\end{array}$ & $\begin{array}{l}\text { Synthetic } \\
\text { Urine }\end{array}$ & Glucose & $\begin{array}{l}\text { SEM with EDAX } \\
\text { and AFM }\end{array}$ & $\begin{array}{l}\text { The corrosion resistance } \\
\text { decreased at low } \\
\text { concentrations and increased } \\
\text { at higher concentrations. }\end{array}$ \\
\hline 29 & $\begin{array}{l}\text { Cu-Ni-Ti } \\
30\end{array}$ & $\begin{array}{l}\text { Artificial Blood } \\
\text { Plasma } \\
\text { Ti-Ni SMA }\end{array}$ & $\begin{array}{l}\text { Cholesterol } \\
\text { Co-Cr alloy }\end{array}$ & $\begin{array}{l}\text { Potentiodynamic } \\
\text { polarisation } \\
\text { AC Impendance } \\
\text { system }\end{array}$ & $\begin{array}{l}\text { Maximum Corrosion resistance } \\
\text { was observed in 100ppm of } \\
\text { Cholesterol than with 50ppm } \\
\text { and in absence of Cholesterol }\end{array}$ \\
\hline Solution
\end{tabular}

\section{CONCLUSION}

The artificial biomaterials implanted inside the human body in the place of bone, teeth, and even organs are being medically substituted with different types of metals such as mild steel, carbon steel, Ni-Cr alloy, Fe-Cr alloy, 22 carat Gold, 24 carat Gold, Tin, etc. and the studies were summarized. Corrosion resistance studies such as polarisation, AC impedance, cyclic voltammetric studies conducted in mediums like artificial blood plasma, artificial urine, artificial salvia, artificial sweat, Hank solution, Ringer solution, etc. were determined. Future Research on the field of Corrosion Resistance of various biomaterials can be analysed and studied for the betterment of implantation in the field of medicine.

\section{REFERENCES}

[1] R.Joseph Rathish, S.Rajendran, J.Lydia Christy, B. Shyamala Devi, S.Johnmary, M.Manivannan, K. Rajam, P.Rengan (2010) Corrosion Behaviour of Metals in Artificial Sweat, The Open Corrosion Journal, 3, 38-44.

[2] R.Nagalakshmi, S.Rajendran, J.Sathiyabama (2013) Corrosion Inhibitive Effect of Metal and alloy in artificial Urine in presence of Urea, International Journal of Advances in Engineering and Technology, 6(4), 1914-1921.

[3] A.Ch. Catherine Mary, S.Rajendran, J.Jeyasundari (2017) Influence of coffee on the corrosion resistance of orthodontic wires in artificial saliva, European Chemical Bulletin, 6(6), 232-237.

[4] S.Rajendran, V.Uma, A.Krishnaveni, J.Jeyasundari, B.Shyamaladevi, M.Manivannan (2009) Corrosion behaviour of metals in artificial saliva in presence of D-Glucose, The Arabian Journal for Science and Engineering, 34(2C), 147-158.

[5] L.Liu, C.L.Qiu, Q.Chen, S.M.Zhang (2006) Corrosion behavior of Zr-based bulk metallic glasses in different artificial body fluids, Journal of Alloys and Compounds, 425, 268-273.
[6] M.B.Petrović Mihajlović, M.B.Radovanović, A.T. Simonović, Ž.Z.Tasić, M.M.Antonijević (2019) Evaluation of purine based compounds as the inhibitors of copper corrosion in simulated body fluid, Results in Physics, 14, 102357.

[7] N.Saha, J.Basu, P.Sen, G.Majumdar (2020) Electrochemical behaviour of martensitic stainless steel with blood, Materials Today: Proceedings, 26(2), 677-680.

[8] Hu.Yang, K.Yang, B.Zhang (2006) Pitting Corrosion resistance of $\mathrm{La}$ added $316 \mathrm{~L}$ stainless steel in simulated body fluids, Materials Letters, 61(4-5), 1154-1157.

[9] Yu.Tsutsumi, Yo.Takano, H.Doi, K.Noda, T.Hanawa (2007) Corrosion Behaviour of Zirconium based alloys in Simulated Body Fluids, Trans Tech Publications, Switzerland, Materials Science Forum, 561-565, 1489-1492.

[10] M.P.Nikolova, E.H.Yankov (2019) Corrosion Study of Ti5Al4V and Ti6Al4V in different Simulated Body fluids, Springer Nature Switzerland AG 2019 L. F. M. da Silva (ed.), Materials Design and Applications II, Advanced Structured Materials 98.

[11] M. Sharma, A.V. Ramesh Kumar, N. Singh, N.Adya, B.Saluja (2008) Electrochemical Corrosion Behavior of Dental/Implant Alloys in Artificial Saliva, Journal of Materials Engineering and Performance, 17(5), 687-695.

[12] S.John Mary, S.Rajendran (2013) Corrosion Behaviour of SS316L in Artificial Blood Plasma in Presence of Amoxicillin Portugaliae, Electrochimica Acta, 31(1), 33-40.

[13] S.Rajendran, J.Paulraj, P.Rengan, J.Jeyasundari, M.Manivannan (2009) Corrosion behaviour of metals in artificial saliva in presence of spirulina powder, Journal of Dentistry and Oral Hygiene, 1(1), 001-008.

[14] S.Gowri, B.Jaslin Lara, B.Kanagamani, A.Kavitha, A.Maria Belciya, C.Muthunayaki, C.Pandeeswari, J. Maria Praveena, T.Umasankareswari, L.Jerald Majellah, S.Rajendran (2020) Influence of Metformin Hydrochloride- $250 \mathrm{mg}$ (MFH) tablet on Corrosion Resistance of orthodontic wire made of $\mathrm{NiCr}$ alloy in Artificial Saliva, J Chem Sci Chem Engg, 1(1), 1-10. 
[15] M.M.El-Rabiei, A.Bahrawy, H.E.El-Feky, MosaadNegem, M.M.Safaa, H.Nady (2020) The Effect of Ni Content on the Corrosion Resistance of Some $\mathrm{Fe}-\mathrm{Cr}-\mathrm{Ni}$ Alloys in Simulated Body Fluids in the Presence of $\mathrm{H}_{2} \mathrm{O}_{2}$ and Albumin, Journal of Bioand Tribo-Corrosion, 6, 52-61.

[16] R.Nagalakshmi, S.Rajendran, J.Sathiyabama, M.Pandiarajan, J.Lydia Christy (2013) Corrosion behaviour of metals in Artificial Urine in presence of Sodium Chloride,European Chemical Bulletin, 2(4), 150-153.

[17] S.Agiladevi, S.Rajendran (2019) Electrochemical studies on the corrosion behaviour of metals and alloys in simulated ringer 's solution, Rasayan Journal of Chemistry, 12(1), $22-31$.

[18] W. Kajzer, A.Krauze, W.Walke, J.Marciniak (2006) Corrosion resistance of $\mathrm{Cr}-\mathrm{Ni}$-Mo steel in simulated body fluids, Journal of Achievements in Materials and Manufacturing Engineering, 18(1-2), 56-64.

[19] I.M.Pohrelyuk, O.V.Tkachuk, R.V.Proskurnyak (2012) Corrosion Behaviour of Ti-6Al-4V Alloy with Nitride Coatings in Simulated Body Fluids at $36^{\circ} \mathrm{C}$ and $40^{\circ} \mathrm{C}$, Hindawi Publishing Corporation ISRN Corrosion, 2013, ID 241830.

[20] Z.Ahmadian, I.Danaee, M.A.Golozar (2014) Effect of surface treatment on Corrosion Resistance of 304 Stainless Steel implants in Tyrode solution, Archives of metallurgy and materials, 59(1), 25-30.

[21] V.Agnes Brigitta, C.Thangavelu, S.Rajendran, A.AlHashem (2018) Corrosion resistance of SS18/8 alloy, SS316L alloy, Gold18carat and Gold 22 carat in artificial saliva in the absence and presence of erythromycin tablet $500 \mathrm{mg}$, Zastita Materijala, 59(2), 182-189.

[22] F.T.Cheng, K.H.Lo, H.C.Man (2006) An electrochemical study of the crevice corrosion resistance of $\mathrm{NiTi}$ in Hanks' solution, Journal of Alloys and Compounds, 437, 322-328.

[23] W.Walke, Z.Paszenda, A.Ziêbowicz (2007) Corrosion behaviour of Co-Cr-W-Ni alloy in diverse body fluids, International Scientific Journal, 28(5), 293-296.

[24] K.Elagli, M.Traisneland H.F.Hildebrand (1993) Electrochemical behaviour of Titanium and Dental Alloys in Artificial Saliva, Elecrrochim Aiccata, 38(13), 1769-1776.

[25] A.M.Fekry, R.M.El-Sherif (2009) Electrochemical corrosion behavior of magnesium and titanium alloys in simulated body fluid, Electrochimica Acta, 54, 7280-7285.

[26] Ch.Lu, Yu.Zheng, Qu.Zhong (2017) Corrosion of dental alloys in artificial saliva with Streptococcus mutans, PLoS ONE, 12(3), e0174440.

[27] S.John Mary, S.Rajendran (2013) Corrosion behaviour of metals in artificial blood plasma in presence of glucose, Portugaliae Electrochimica Acta, 31(1), 33-40.
[28] S.John Mary, G.Puthlibai, P. Kathiravan, J. Mano Deepa, A.Selvam (2021) Electrochemical behaviour of $\mathrm{Ni}-\mathrm{Ti}$ (Super elastic) alloy in artificial saliva in the presence of Phexin, Materials today proceedings, 36(4), 878-882.

[29] A.Ch.Catherine Mary, S.Rajendran, J. Jeyasundari, R. Dorothy (2017) Corrosion resistance of $\mathrm{Ni}-\mathrm{Ti}$ alloy, SS18/8 alloy and thermoactive alloy in artificial saliva in the absence and presence of tea, Zastita Materijala, 55(3), 244-250.

[30] R.Nagalakshmi, J.Sathiyabama, I.Ameeth Basha, S.Johnmary (2017) Invitro Corrosion studies on Nickel Titanium Super elastic alloy in synthetic urine in presence of D- Glucose , International Journal of Materials Science, 12( 2), 51-59.

[31] S.John Mary, S.Rajendran (2014) Corrosion behavior of $\mathrm{Cu}-\mathrm{Ni}-\mathrm{Ti}$ in artificial blood plasma in presence of cholesterol, Zastita Materijala, 55(3),244-250.

[32] Ch.Liang, R.Zheng, N.Huang, B.Wu (2010) Electrochemical behaviour of Ti-Ni SMA and $\mathrm{Co}-\mathrm{Cr}$ alloys in dynamic Tyrode's simulated body fluid, J Mater Sci Mater Med, 21, 1421-1426.

[33] J.Kamiński, K.Małkiewicz, J.Rębiś, T.Wierzchoń (2020) The effect of glow discharge nitriding on the corrosion resistance of stainless steel orthodontic arches in artificial saliva solution, Archives of Metallurgy and Materials, 65(1),375-384.

[34] J.Affi, F.Ihsan, H.Fajri, P.Gunawarman (2019) Corrosion Behavior of New Type Titanium Alloy As Candidate for Dental Wires in Artificial Saliva on Fluctuating Temperatures, IOP, Conference Series: Materials Science and Engineering, 547(1), 012022.

[35] E.Erwansyah, C.Susilowati (2019) The effect of snake fruit extract (Salaccazalacca) in inhibiting the release of Chromium ( $\mathrm{Cr}$ ) and $\mathrm{Nickel}(\mathrm{Ni})$ ion from stainless steel orthodontic wire to saliva, International Journal of Applied Pharmaceutics, 11(4), 3336-3344.

[36] D.R.Nahusona, P.Koriston (2019) The effectiveness of watermelon rind extract as corrosion inhibitor in stainless steel orthodontic wire, International Journal of Applied Pharmaceutics, 11(4), 2225-2233.

[37] I.Musa Trolic, N.L.Serdarevic, Z.Todoric, A.Budimir, S.Spalj, H.Otmacic Curkovic (2019) Corrosion of orthodontic archwires in artificial saliva in the presence of Lactobacillus reuteri, Surface and Coatings Technology, 370, 44-52.

[38] M.R. Sharma, N.Mahato, M.H. Cho,T.P.Chaturvedi, M.M. Singh (2019) Effect of fruit juices and chloride ions on the corrosion behavior of orthodontic archwire, Materials Technology, 34(1), 18-24.

[39] B.Ziębowicz, A.Woźniak, A.Ziębowicz, A. Ziembińska-Buczyńska (2019) Analysis of the surface geometry of the orthodontic archwire and their influence on the bacterial adhesion, Journal of Achievements in Materials and Manufacturing Engineering, 93(1-2), 32-40. 


\section{IZVOD}

\section{ELEKTROHEMIJSKO PONAŠANJE RAZLIČITIH METALA ZA IMPLANTACIJU U PRISUSTVU RAZLIČITIH SIMULIRANIH TELESNIH TEČNOSTI - PREGLED}

U savremenoj medicini metali i legure se koriste kao implantati. Proučava se ponašanje korozije različitih biomaterijala u veštačkim telesnim tečnostima. U ljudsko telo se ugrađuju veštački biomaterijali koji zamenjuju kosti, zube itd. Čak se $i$ organi medicinski zamjenjuju različitim vrstama metala, poput mekog čelika, ugljeničnog čelika, legure $\mathrm{Ni}-\mathrm{Cr}$, legure $\mathrm{Fe}-\mathrm{Cr}$, 22-karatnog zlata, 24-karatnog zlatnog kalaja itd., zbog njihove biokompatibilnosti. To se postiže povezivanjem ovih metala direktno sa tkivima tela. Metali imaju tendenciju korozije kada dođu u kontakt sa tečnostima ljudskog tela. Telesne tečnosti na taj način dolaze u direktan kontakt sa tkivima, a tkiva su u kontaktu sa metalom i na taj način izazivaju koroziju metala. Stoga se studije otpornosti na koroziju, poput polarizacije, impedanse naizmenične struje, cikličnih voltametrijskih studija itd., sprovode u medijumu poput veštačke krvne plazme, veštačkog urina, veštačke salvije, veštačkog znoja, Henkovog rastvora, Ringerovog rastvora itd. Tečnosti se ispituju u prisustvu različitih implantacionih metala elektrohemijskim metodama i formiraju se zaštitni filmovi koji se analiziraju različitim tehnikama površinske analize kao što su AFM, FTIR-UV, SEM itd. Nalazi istraživanja će time biti od velike pomoći medicinskom polju.

Ključne reči: Korozija, Henkov rastvor, legura, veštačke telesne tečnosti.

\section{Pregledni rad}

Rad primljen: 01. 07. 2021.

Rad korigovan: 20. 07. 2021.

Rad prihvacen: 27. 07. 2021.

Rad je dostupan na sajtu: www.idk.org.rs/casopis

(C) 2021 Authors. Published by Engineering Society for Corrosion. This article is an open access article distributed under the terms and conditions of the Creative Commons Attribution 4.0 International license (https://creativecommons.org/licenses/by/4.0/) 